\author{
Izabela Grabowska \\ Instytut Statystyki i Demografii \\ Szkoła Główna Handlowa w Warszawie \\ Institute of Statistics and Demography \\ Warsaw School of Economics \\ igrabow@sgh.waw.pl \\ Ewelina Stotwińska-Rosłanowska \\ Instytut Statystyki i Demografii \\ Szkoła Główna Handlowa w Warszawie \\ Institute of Statistics and Demography \\ Warsaw School of Economics \\ eslotw@sgh.waw.pl
}

KONFLIKT POMIĘDZY PRACĄ ZAWODOWĄ
A OBOWIĄZKAMI RODZINNYMI W POLSCE

\title{
WPROWADZENIE
}

W krajach rozwiniętych, w ciągu ostatnich dziesięcioleci zaobserwować można wzrost napięcia pomiędzy pracą zawodową a obowiązkami rodzinnymi (Duxbury i Higgins 2001, Marks 2006). Z jednej strony, coraz większe jest zaangażowanie pracowników, szczególnie kobiet, w pracę zawodową, co przejawia się rosnącym udziałem pracujących kobiet, dłuższym czasem pracy, rosnącymi wymaganiami pracodawców. Z drugiej strony, niezmienna pozostaje konieczność wykonywania obowiązków domowych, które w dużej mierze realizują - ponownie - kobiety. Godzenie oczekiwań dotyczących realizacji obowiązków zawodowych oraz tych wynikających ze zobowiązań rodzinnych stanowi istotne wyzwanie. Na istnienie konfliktu pomiędzy pracą zawodową a rodziną po raz pierwszy zwrócono uwagę w drugiej połowie XX wieku. Khan i in. (1964) podjęli próbę zdefiniowania pojęcia konfliktu na linii praca-rodzina wskazując, że wyznacza go niemożność realizacji nakładanych w obu sferach obowiązków w zadanym czasie. Dwie dekady później Greenhaus i Beutell (1985) uznali, że konflikt pomiędzy pracą zawodową a życiem rodzinnym ma miejsce $\mathrm{w}$ sytuacji, gdy wymagania nakładane na jednostkę $\mathrm{w}$ jednym $z$ tych obszarów wpływają niekorzystnie na jej zdolność do spełnienia wymagań stawianych w drugim z obszarów. 
Konflikt pomiędzy pracą zawodową a życiem rodzinnym może przyjmować postać (Greenhaus i Beutell 1985, Peters i in. 2009):

- konfliktu czasu (ang. time-based conflict), polegającego na tym, że jednostka nie jest $\mathrm{w}$ stanie zrealizować $\mathrm{w}$ danym czasie wszystkich stawianych przed nią zadań zawodowych i rodzinnych, a zatem realizacja zadania wynikającego z jednej z ról uniemożliwia wywiązanie się ze zobowiązań w drugiej roli,

- konfliktu związanego z napięciem (ang. strain-based conflict), który występuje wówczas, gdy napięcie związane $\mathrm{z}$ funkcjonowaniem $\mathrm{w}$ jednym $\mathrm{z}$ obszarów jest na tyle duże, że uniemożliwia realizację zadań wynikających z drugiej z ról, - konfliktu zachowań (ang. behavior-based conflict), który jest wynikiem odmiennych oczekiwań co do wzorca zachowań w każdej z ról.

Niezależnie od tego, która z powyższych form konfliktu dominuje w danej sytuacji, samo istnienie konfliktu na linii praca-rodzina ma negatywny wpływ zarówno na życie zawodowe, jak i rodzinne (Allen i in. 2000). Można też przedstawić inną klasyfikację typów konfliktu pomiędzy pracą zawodową a życiem rodzinnym, wyróżnioną ze względu na rodzaj relacji pomiędzy rozpatrywanymi obszarami:

- konflikt rodzina-praca (ang. family-work conflict), polegający na tym, że nadmierne obciążenie obowiązkami rodzinnymi istotnie utrudnia bądź uniemożliwia realizację obowiązków zawodowych, oraz

- konflikt praca-rodzina (ang. work-family conflict), gdy nadmiar obowiązków zawodowych wpływa negatywnie na zdolność realizacji obowiązków rodzinnych.

Powyższe rodzaje konfliktu, choć ściśle ze sobą związane, są rozłączne (Gutek i in. 1991, Adams i in. 1996). I choć wiele opracowań dotyczy zjawiska konfliktu bez rozróżniania jego formy (np. Voydanoff 1988, Winslow 2005), coraz częściej badacze odrębnie odnoszą się do zagadnienia zakłócania możliwości realizacji obowiązków rodzinnych przez życie zawodowe i odwrotnie (np. Hill 2005, Minnotte $i$ in. 2010, Pedersen i in. 2009, Voydanoff 2005a, b).

Przyczyn konfliktu poszukuje się zwykle w dwóch obszarach, będących jego potencjalnymi źródłami. Pierwszy dotyczy wykonywanej pracy zawodowej, jej organizacji, warunków i intensywności (np. Bowen 1998, Hill i in. 2008, Notten i in. 2017, Ruppanner i Pixley 2012). Drugi zaś dotyczy sytuacji rodzinnej respondenta, związanej głównie ze składem gospodarstwa domowego, obecnością dzieci lub dorosłych wymagających opieki (Byron 2005, Kocot-Górecka i Kurowska 2013, Notten i in. 2017). Z kolei obecność tych osób wiąże się zwykle z fazami przebiegu życia rodziny, zgodnie z którymi zmianom ulega skład członków gospodarstwa domowego, a także natężenie konfliktu pomiędzy obowiązkami rodzinnymi i zawodowymi. Nie bez znaczenia jest także obecność w gospodarstwie domowym osób, które mogą pomóc w łączeniu obowiązków rodzinnych i zawodowych, w szczególności partnera, a także podział obowiązków rodzinnych pomiędzy kobietami i mężczyznami.

Napięcia pomiędzy wykonywaniem obowiązków rodzinnych i zawodowych wydają się mieć szczególne znaczenie w polskim kontekście. W Polsce dominującym modelem rodziny jest tzw. model podwójnego żywiciela (ang. dual earner model), 
w którym oboje partnerzy pracują zawodowo, jednak wynagrodzenie mężczyzn jest z reguły wyższe niż kobiet (Kotowska i in. 2007). Jednocześnie, kobiety są zazwyczaj w większym stopniu zaangażowane w obowiązki domowe (Kocot-Górecka i Kurowska 2013). Tematyka konfliktu pomiędzy obowiązkami rodzinnymi i zawodowymi była jednak w badaniach polskich podejmowana zdecydowanie rzadziej niż w krajach Europy Zachodniej. Najczęściej badania nad tym zagadnieniem podchodzą do przedmiotu dość wąsko i dotyczą na przykład zmiany poziomu satysfakcji z pracy w różnych fazach życia (Zalewska 2011) czy natężenia konfliktu w zależności od zadowolenia z relacji w związku (Kaźmierczak i Chybicka 2008). Celem niniejszego artykułu jest analiza nasilenia konfliktu pomiędzy pracą zawodową a obowiązkami rodzinnymi w sposób całościowy. Wyodrębniamy zarówno konflikt na linii pracarodzina, tj. gdy praca zawodowa zakłóca realizację obowiązków rodzinnych, jak i konflikt na linii rodzina-praca, tj. gdy obowiązki rodzinne oddziałują na wykonywanie pracy zawodowej. Naszym celem jest także próba identyfikacji determinant konfliktu między życiem zawodowym i rodzinnym w polskim kontekście.

\section{PYTANIA BADAWCZE}

Jak wynika z dotychczasowych badań (np. Comer i Stites-Doe 2006), na poziom konfliktu praca-rodzina i rodzina-praca wpływają przede wszystkim obowiązki związane z wychowywaniem dzieci. Przyjmując zatem, że osoby posiadające dzieci są narażone na występowanie obu rodzajów konfliktu w stopniu znacznie większym niż osoby bezdzietne (Bianchi i Milkie 2010, Craig i Bittman 2008, Gauthier i Furstenberg 2002), w niniejszym badaniu koncentrujemy się na sytuacji rodziców dzieci w wieku do 14 lat.

Ponadto konieczne wydaje się osobne spojrzenie na sytuację kobiet i mężczyzn. Wyniki dotychczasowych badań sugerują bowiem, że sposób postrzegania konfliktu pomiędzy pracą zawodową i rodzinną, jego nasilenie i determinanty mogą być różne dla każdej z płci (Baxter 2002). Wyjaśniając źródła tych różnic, badacze wskazują najczęściej na odmienne oczekiwania odnośnie do ról kobiet i mężczyzn, w szczególności w zakresie zaangażowania w obowiązki związane ze sprawowaniem opieki nad dziećmi oraz pracę zawodową (Hartmann 2004), a także na nierówny podział obowiązków domowych w gospodarstwach domowych z dwojgiem pracujących rodziców (Dilworth 2004, van der Lippe i van Dijk 2001).

Biorąc pod uwagę powyższe przesłanki, ogólne pytanie badawcze, na które poszukujemy odpowiedzi w niniejszym artykule, brzmi:

Jakie sa determinanty konfliktu na linii rodzina-praca i praca-rodzina dla kobiet i mężczyzn, rodziców dzieci do lat 14 w Polsce?

Przypuszczamy, że chociaż model rodziny, w którym dwoje rodziców pracuje zawodowo występuje obecnie najczęściej, to poziom konfliktu rodzina-praca będzie wyższy u kobiet niż u mężczyzn. Dzieje się tak ponieważ kobiety są bardziej obcią- 
żone obowiązkami domowymi. Spodziewamy się też, że konflikt praca-rodzina będzie wyższy u mężczyzn niż u kobiet, ponieważ to na mężczyznach spoczywa większa odpowiedzialność za utrzymanie rodziny. Wreszcie, dopuszczamy, że determinanty obu tych konfliktów mogą się różnić dla kobiet i mężczyzn.

Wyniki wcześniejszych badań wskazują, że niezależnie od tego, czy analizie poddajemy konflikt praca-rodzina, czy rodzina-praca oraz czy patrzymy na sytuację kobiet, czy mężczyzn, to poziom konfliktu pomiędzy pracą zawodową a rodziną zależny jest zarówno od sytuacji rodzinnej respondenta, jak i od charakterystyki jego otoczenia, w tym miejsca pracy (np. Ruppanner i Pixley 2012). Dlatego, w niniejszych badaniach, determinant konfliktu praca-rodzina oraz rodzina-praca, poszukujemy w następujących obszarach:

- charakterystyce miejsca pracy respondenta, w odniesieniu do której przyglądamy się m.in. formie i wymiarowi zatrudnienia, jego subiektywnie odbieranej stabilności oraz stosowanym przez pracodawcę instrumentom wspierającym łączenie przez pracowników obowiązków zawodowych i rodzinnych (zgodnie z wiedzą respondenta),

- sytuacji rodzinnej respondenta, ze szczególnym uwzględnieniem składu rodziny respondenta, w tym obecności partnera oraz liczby i wieku dzieci.

Biorąc pod uwagę dwa powyższe obszary, nasze ogólne pytanie badawcze może zostać sprowadzone do następujących dwóch pytań szczegółowych:

(1) Czy cechy miejsca pracy ksztaltujące organizację $i$ warunki pracy, a $w$ szczególności czas poświęcany tygodniowo na pracę, nadzór nad praca innych oraz możliwość elastycznego ksztaltowania czasu pracy i zadowolenie z pracy maja znaczenie dla obu rodzajów konfliktów?

Analiza przeprowadzonych dotychczas w tym zakresie badań pozwala na identyfikację charakterystyk miejsca pracy, które mogą istotnie determinować poziom konfliktu pomiędzy pracą zawodową a rodziną. Przypuszczamy, że szczególnie w odniesieniu do konfliktu praca-rodzina i zgodnie z dotychczasowymi ustaleniami badaczy (np. Bowen 1998, Byron 2005, Dilworth 2004, Notten i in. 2017, Ruppanner i Pixley, 2012), większemu zaangażowaniu w pracę zawodową (czas pracy) towarzyszyć będzie wyższy poziom konfliktu. $Z$ uwagi na charakter zadań i związany z nimi stres, silniejszego konfliktu (szczególnie na linii praca-rodzina) spodziewamy się również u osób wykonujących pracę związaną z nadzorem innych pracowników (por. Maume i Houston 2001). Jak wynika z wcześniejszych badań, stopień, w jakim praca zawodowa zakłóca możliwość realizowania obowiązków rodzinnych powinny natomiast łagodzić: poczucie stabilności zatrudnienia (np. Cooklin i in. 2015, Lawrence $i$ in. 2013) oraz możliwość korzystania z rozwiązań pozwalających na elastyczne kształtowanie godzin pracy (np. Bond i in. 2003, Byron 2005, Hill i in. 2008).

W zakresie związku charakterystyk miejsca pracy z poziomem konfliktu rodzinapraca oczekujemy, że będzie on mniejszy niż związek ze stopniem, w jakim to praca 
zakłóca możliwość wykonywania obowiązków domowych. Z uwagi jednak na przenikanie się tych dwóch sfer życia, możliwe jest ujawnienie się znaczenia organizacji i warunków pracy dla poziomu konfliktu rodzina-praca. W szczególności dotyczy to tych charakterystyk miejsca pracy, które najbardziej determinują możliwość łączenia życia rodzinnego $\mathrm{z}$ pracą zawodową, $\mathrm{tj}$. czasu poświęcanego na pracę zawodową oraz możliwości korzystania z elastycznych form zatrudnienia (por. Bond i in. 2003, Bowen 1998, Hill i in. 2008, Notten i in. 2017, Ruppanner i Pixley 2012).

(2) Czy sytuacja rodzinna respondenta, $w$ tym liczba dzieci do lat $14 w$ gospodarstwie domowym, ich wiek oraz obecność partnera ma zwiazek z natężeniem obu rodzajów konfliktów u rodziców?

Bazując na dotychczasowych ustaleniach badaczy (np. Keene i Quadagno 2004, Notten i in. 2017) oczekujemy, że liczba posiadanych dzieci oraz ich wiek determinować będą w szczególności nasilenie konfliktu rodzina-praca. Konflikt ten będzie wyższy w rodzinach o większej liczbie dzieci oraz w rodzinach z małymi dziećmi. Konflikt ten powinna jednak łagodzić, szczególnie w odniesieniu do mężczyzn, obecność w gospodarstwie domowym partnera, z którym respondent może dzielić obowiązki domowe. Chociaż oczekujemy, że znaczenie sytuacji rodzinnej respondenta dla poziomu konfliktu praca-rodzina nie będzie tak silne, jak w przypadku konfliktu rodzina-praca, oczekujemy ujawnienia się istotnego związku pomiędzy poziomem tego zakłócenia a liczbą i wiekiem dzieci oraz posiadaniem partnera.

Wyżej wymienione determinanty mogą mieć odmienne znaczenie dla kobiet i mężczyzn. Dodatkową wartością naszego badania jest zatem to, że pozwoli ono ocenić, w jakim zakresie te same determinanty są istotne dla konfliktu rodzina-praca oraz praca-rodzina u obu płci. Spodziewamy się, że wobec faktu, iż to matki są głównymi osobami odpowiedzialnymi za opiekę nad dziećmi, dla kobiet ważnymi determinantami konfliktu praca-rodzina będą te charakterystyki miejsca pracy, które sprzyjają łączeniu pracy z życiem rodzinnym, a dla konfliktu rodzina-praca - liczba i wiek dzieci.

\section{METODA I DANE}

Analiza została zrealizowana na podstawie danych zebranych w drugiej rundzie badania Generacje i Rodziny (ang. Gender and Generation Survey, GGS), przeprowadzonego na przełomie 2014 i 2015 roku na próbie 13896 respondentów w wieku 18-79 lat. Grupę respondentów, dla których przeprowadziłyśmy analizę, ograniczyłyśmy zgodnie z postawionymi celami badania do pracujących rodziców posiadających dzieci do lat 14 i współzamieszkujących $\mathrm{z}$ nimi. W analizie nie uwzględniłyśmy osób pracujących na własny rachunek ze względu na fakt, że nie zadano im niektórych pytań dotyczących środowiska pracy, istotnych dla celów niniejszego badania. Ostatecznie próba analityczna liczyła 933 osoby, z czego 396 stanowiły kobiety, a 537 mężczyźni. Następnie dokonałyśmy operacjonalizacji zmiennych świadczą- 
cych o nasileniu konfliktów w zakresie łączenia obowiązków rodzinnych i zawodowych (zmiennych zależnych w modelu).

Pierwszym z badanych konfliktów był konflikt rodzina-praca. Za miarę poziomu tego konfliktu przyjęto średnią rangę $\mathrm{z}$ odpowiedzi na pytania dotyczące tego, ile razy ciągu ostatnich 3 miesięcy:

- z powodu wykonanych prac domowych respondent przyszedł do pracy zbyt zmęczony, żeby sprawnie funkcjonować, oraz

- trudno było respondentowi skoncentrować się w pracy z powodu obowiązków rodzinnych.

Analogicznie, miarą poziomu konfliktu pomiędzy pracą a rodziną (zmienną zależną w modelu opisującym konflikt praca-rodzina) była średnia ranga $\mathrm{z}$ odpowiedzi na pytania dotyczące tego, ile razy w ciągu ostatnich 3 miesięcy:

- respondent wrócił z pracy zbyt zmęczony, żeby wykonać konieczne prace domowe, oraz

- trudno było respondentowi wypełnić obowiązki rodzinne z powodu ilości czasu, jaki poświęcił pracy zawodowej.

W odpowiedzi na każde z wyżej wymienionych pytań respondent wskazywał jedną z następujących częstotliwości doświadczania opisanego zdarzenia: 1 - kilka razy w tygodniu, 2 - kilka razy w miesiącu (więcej niż dwa), 3 - raz lub dwa razy w miesiącu, 4 - nigdy. Tak zdefiniowane nasilenie konfliktu, zarówno konfliktu praca-rodzina, jak i rodzina-praca, zostało zmierzone za pomocą siedmiostopniowej skali, gdzie wartość 1 (najniższa wartość zmiennej) odpowiadała najwyższemu poziomowi konfliktu, a wartość 4 (najwyższa wartość zmiennej) odpowiadała najniższemu poziomowi konfliktu (por. też Rysunek 1 i 2 ). Zmienne określające poziom tych dwóch rodzajów konfliktu stały się zmiennymi zależnymi w szacowanych przez nas modelach ekonometrycznych.

$\mathrm{Na}$ dalszym etapie badania dokonałyśmy operacjonalizacji zmiennych niezależnych. We wszystkich modelach uwzględniłyśmy ten sam zestaw zmiennych niezależnych (objaśniających), co pozwoliło wskazać wpływ poszczególnych zmiennych na oba rodzaje konfliktów dla każdej z płci. W modelu znajdują się następujące zmienne niezależne ${ }^{1}$ (por. też Załącznik nr 1):

1. W zakresie charakterystyki miejsca pracy:

- tygodniowy czas pracy (w godzinach),

- tygodniowy czas pracy podniesiony do kwadratu (w godzinach $\left.{ }^{2}\right)^{2}$,

- możliwość ustalania czasu pracy dostosowanego do potrzeb (tak lub nie),

- lokalizacja miejsca wykonywania pracy (w różnych miejscach poza domem, zwykle w domu lub częściowo w domu lub częściowo poza, w jednym miejscu poza domem),

${ }^{1}$ Część odpowiedzi z kafeterii z ankiety dla poszczególnych zmiennych niezależnych została połączona ze względu na małe liczebności.

${ }^{2}$ Zmienną tę uwzględniłyśmy ze względu na możliwość występowania nieliniowej zależności ze zmienną zależną. 
- zadowolenie z pewności i stabilności zatrudnienia (ocenione w skali od 0 całkowicie niezadowolony do 10 - całkowicie zadowolony),

- rodzaj pracy (najemna w sektorze prywatnym lub publicznym),

- rodzaj umowy (umowa o pracę na czas określony, umowa o pracę na czas nieokreślony, pozostałe),

- parytet płci w zatrudnieniu w miejscu pracy (w większości kobiety, w większości mężczyźni, po równo),

- sprawowanie nadzoru nad pracą innych (tak lub nie),

- uzyskiwanie dodatkowych świadczeń pozapłacowych (możliwość kształcenia, dodatkowa opieka medyczna lub ubezpieczenie zdrowotne, korzystanie z mieszkania służbowego, opieka nad dzieckiem - nieodpłatnie lub za niewielką opłatą),

2. W zakresie sytuacji rodzinnej respondenta:

- posiadanie partnera (zamieszkiwanie z partnerem, niezamieszkiwanie z partnerem lub brak partnera),

- liczba dzieci w gospodarstwie domowym,

- wiek najmłodszego dziecka,

- konieczność sprawowania przez respondenta opieki nad osobą dorosłą.

Dodatkowo włączyłyśmy do analizy następujące zmienne kontrolne dotyczące cech społeczno-demograficznych respondenta:

- wiek respondenta (do 34 lat, 35-44 lata, 45 i więcej),

- poziom wykształcenia (wyższe, średnie, zawodowe i niższe),

- klasa miejscowości zamieszkania (wieś, miasto),

- subiektywna ocena stanu zdrowia (oceniane jako dobre lub bardzo dobre, oceniane gorzej niż dobre).

Ze względu na fakt, że zmienne zależne obrazujące poziom konfliktu pomiędzy pracą zawodową a życiem rodzinnym posiadają 7 kategorii, zostały one potraktowane jako zmienne o charakterze quasi-ciągłym, co pozwala na zastosowanie ogólnego modelu linowego wielu zmiennych (OML). Procedura OML umożliwia dokonywanie analizy regresji oraz analizy wariancji dla jednej zmiennej zależnej względem dowolnej liczby czynników i/lub zmiennych niezależnych. W modelu jako predyktory uwzględniać można zarówno zmienne ilościowe, jak i jakościowe. Procedura ta jest odporna na odstępstwa od założenia normalności rozkładu populacji ujętej w analizach, co jest ważne ze względu na zakres i charakter przyjętych zmiennych niezależnych.

\section{WYNIKI ANALIZ}

Prezentacja wyników analiz została podzielona na dwie części. W pierwszej kolejności przedstawiamy rozkład zmiennych obrazujących natężenie konfliktu pomiędzy rodziną a pracą zawodową w dwóch wymiarach: konflikt rodzina-praca i praca-rodzina - odrębnie dla kobiet i mężczyzn. W drugiej części natomiast pre- 
zentujemy wyniki modelowania ekonometrycznego w zakresie determinant obu rodzajów konfliktu, ponownie odrębnie dla każdej płci.

\section{NATĘŻENIE KONFLIKTU POMIĘDZY PRACĄ I RODZINĄ}

Rozkład zmiennych obrazujących natężenie konfliktu rodzina-praca i praca-rodzina, odrębnie dla kobiet i mężczyzn z dziećmi do lat 14 przedstawiają Rysunek 1 i 2. Należy jednak podkreślić, że zaprezentowane na wykresach rozkłady zmiennych dotyczą zbiorowości szerszej niż analizowana próba badawcza (m.in. uwzględniają również pracujących na własny rachunek).

Wstępna analiza wyników przedstawionych na Rysunku 1 i 2 prowadzi do dwóch ogólnych wniosków. Po pierwsze, znacznie częściej mamy do czynienia z negatywnym wpływem pracy na życie rodzinne, niż z negatywną rolą obowiązków rodzinnych dla zobowiązań zawodowych. Po drugie zaś, występuje niewielkie zróżnicowanie natężenia konfliktu według płci. Należy jednak mieć na uwadze, że zaprezentowane wyniki dotyczą subiektywnego odczucia natężenia konfliktu. Jego odczuwanie i definiowanie może być różne w przypadku kobiet i mężczyzn, na co wpływ może mieć szereg czynników kulturowych, związanych m.in. z podziałem ról w rodzinach.

Rysunek 1. Rozkład wartości zmiennej obrazującej poziom konfliktu rodzina-praca* dla matek i ojców dzieci do lat 14 (w \% dla danej płci)

Figure 1. The distribution of the variable describing conflict from family to work* for mothers and fathers of children up to 14 year old (in \% for each gender)

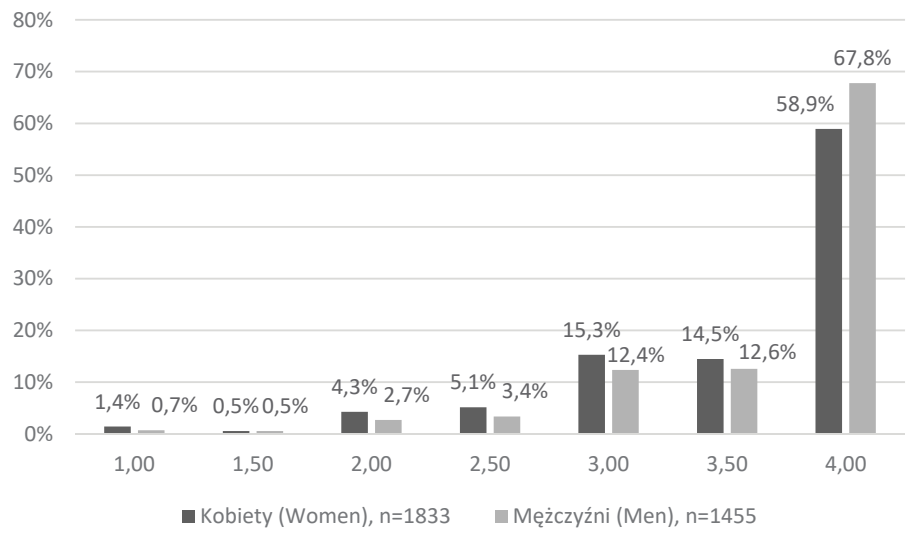

* Zmienna przyjmuje 7 kategorii (od 1 do 4), przy czym wartość najniższa odpowiada najwyższemu natężeniu konfliktu, a najwyższa - najmniejszemu natężeniu konfliktu.

* The variable has 7 categories (from 1 to 4), and the lowest value corresponds to the highest conflict, whereas the highest value - to the lowest conflict.

Źródło: obliczenia własne na podstawie wyników badania Generacje i Rodziny dla Polski, II runda. Source: own calculations based on the Gender and Generations Survey for Poland $-2^{\text {nd }}$ wave. 
Rysunek 2. Rozkład wartości zmiennej obrazującej poziom konfliktu praca-rodzina* dla matek i ojców dzieci do lat 14 (w \% dla danej płci)

Figure 2. The distribution of the variable describing conflict from work to family* for mothers and fathers of children up to 14 year old (in \% for each gender)

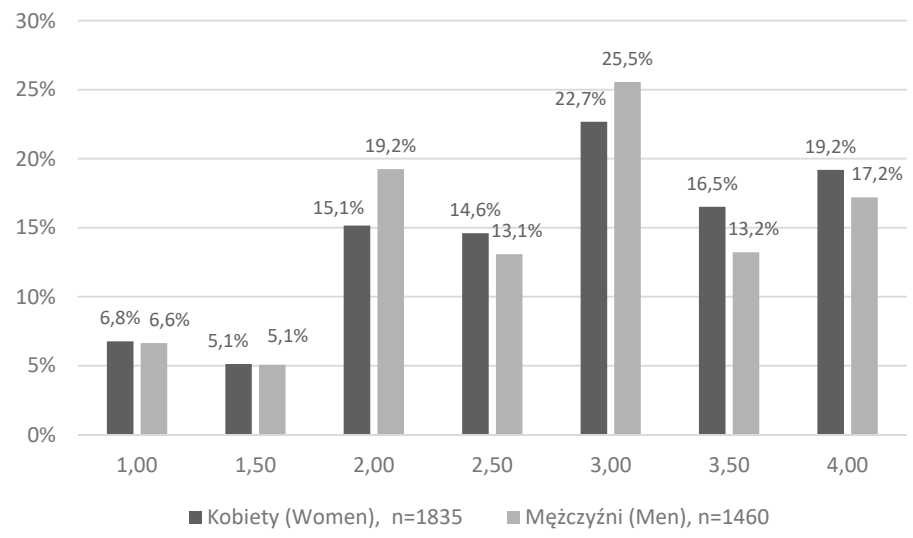

* Zmienna przyjmuje 7 kategorii (od 1 do 4) przy czym wartość najniższa odpowiada najwyższemu natężeniu konfliktu, a najniższa - najmniejszemu natężeniu konfliktu.

* The variable has 7 categories (from 1 to 4), and the lowest value corresponds to the highest conflict, whereas the highest value - to the lowest conflict.

Źródło: obliczenia własne na podstawie wyników badania Generacje i Rodziny dla Polski, II runda. Source: own calculations based on the Gender and Generations Survey for Poland $-2^{\text {nd }}$ wave.

W przypadku konfliktu rodzina-praca poziom jego odczuwalnego natężenia jest niewielki. Aż 59\% matek i 68\% ojców nie doświadczyło negatywnego wpływu obowiązków rodzinnych na wykonywaną pracę. Zaledwie około $12 \%$ matek i $8 \%$ ojców doświadczyło silnego lub umiarkowanego poziomu tego konfliktu (wartość zmiennej od 1 do 2,5).

W przypadku konfliktu praca-rodzina sytuacja prezentuje się odmiennie. Około 17\% ojców i 19\% matek nie doświadczyło negatywnego wpływu pracy na wykonywanie obowiązków rodzinnych. Około 12\% zarówno matek, jak i ojców doświadczyło wysokiego poziomu natężenia tego rodzaju konfliktu (wartość zmiennej nie przekraczająca 1,5). Umiarkowany poziom konfliktu (wartości zmiennej 2 i 2,5) zanotowano u 30\% matek i 32\% ojców. Wciąż jednak ponad połowa matek i ojców albo tego rodzaju konfliktu nie doświadczyła w ogóle, albo jego natężenie było niewielkie.

\section{MODELE EKONOMETRYCZNE}

W Tablicy 1 zaprezentowano wyniki modelowania w zakresie determinant konfliktu pomiędzy pracą zawodową a rodziną oraz rodziną a pracą zawodową. 


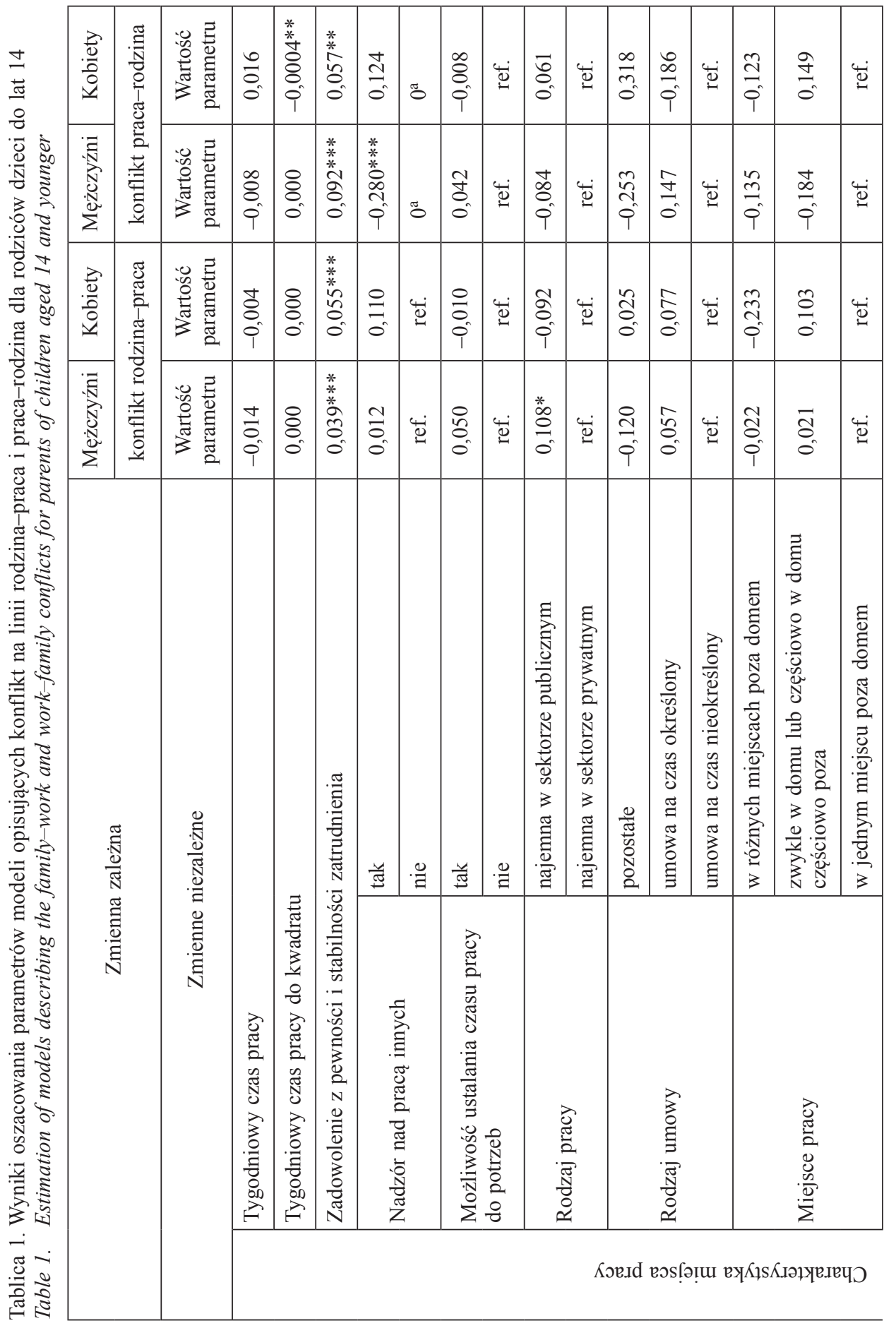




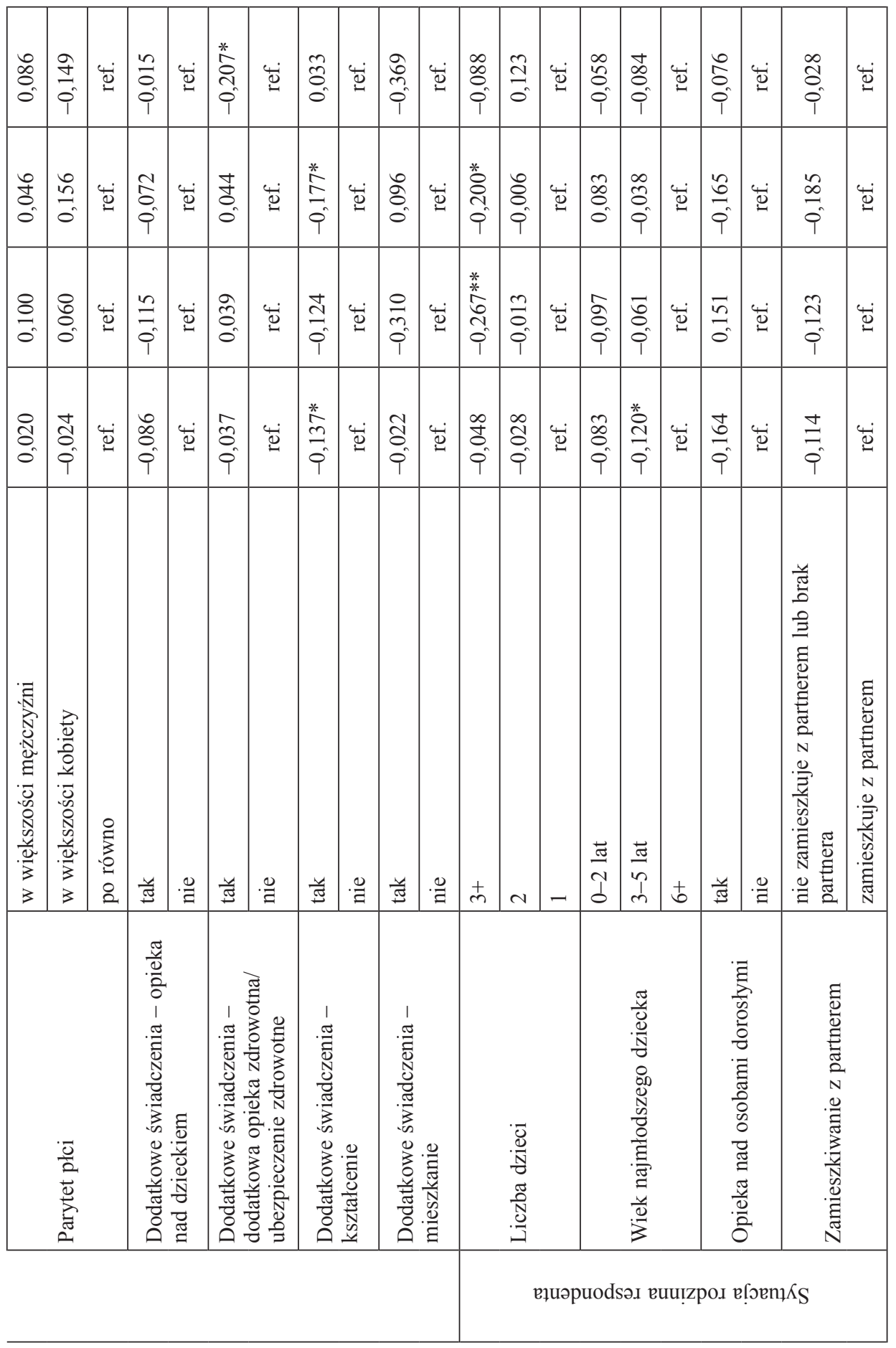



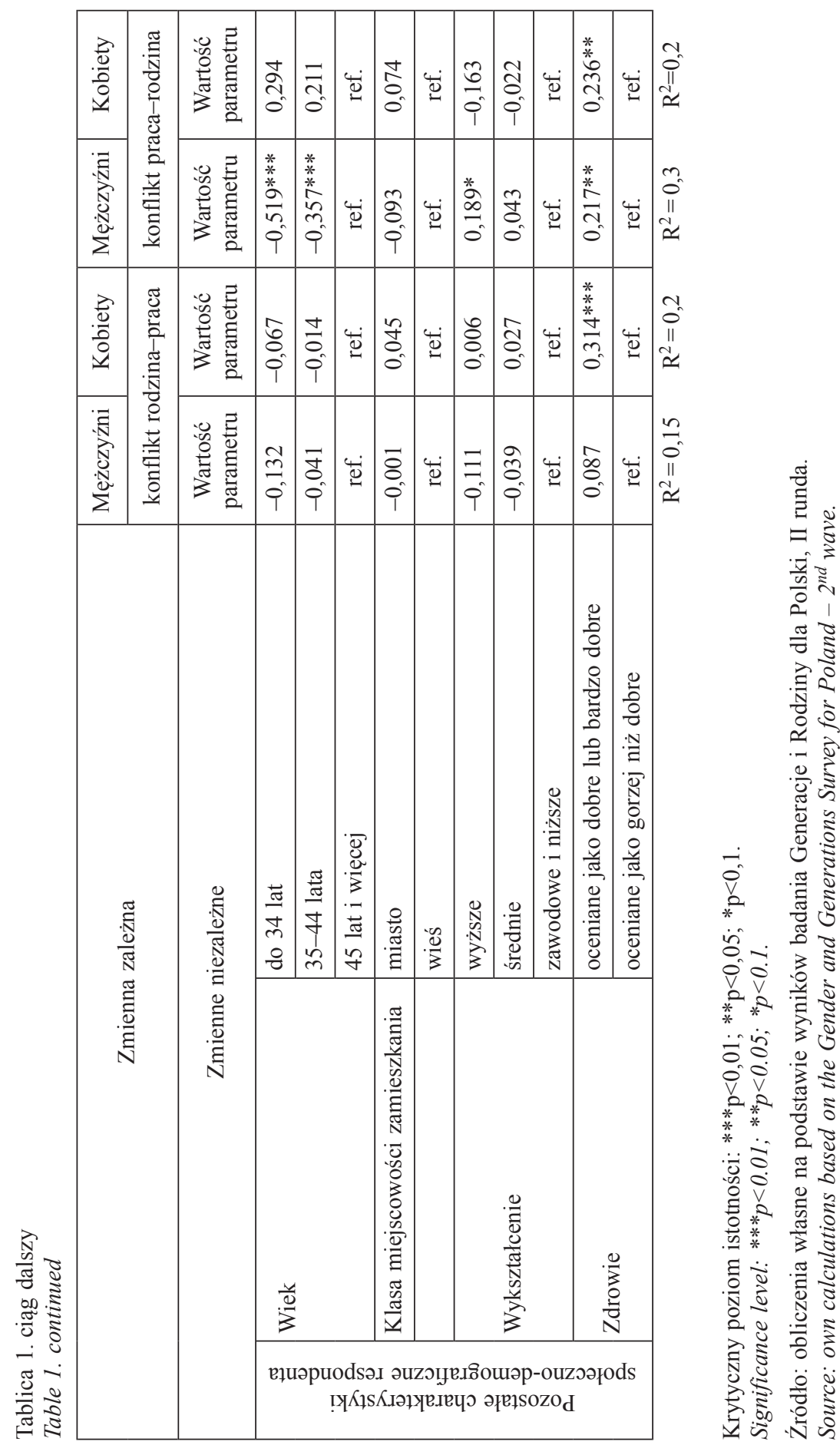


\section{KONFLIKT RODZINA-PRACA}

Odnośnie do charakterystyk miejsca pracy model ujawnił dość ograniczoną rolę miejsca i rodzaju pracy respondenta dla poziomu konfliktu pomiędzy rodziną a pracą zawodową (Tablica 1). Tygodniowy czas pracy nie okazał się istotnie determinować poziomu konfliktu pomiędzy rodziną a pracą zawodową, zarówno dla kobiet, jak i mężczyzn. Wyniki dla Polski nie potwierdziły więc wyników badań prowadzonych dla innych krajów (Bowen 1998, Notten i in. 2017, Ruppanner i Pixley 2012). Poziom konfliktu nie miał również, w przypadku obu płci, związku z faktem wykonywania przez respondenta zadań polegających na nadzorowaniu innych pracowników. Tej zależności nie zdiagnozowano również w badaniu Ruppanner i Pixley (2012).

Bez znaczenia dla poziomu konfliktu, zarówno dla kobiet jak i mężczyzn, okazała się możliwość ustalania czasu pracy stosownie do potrzeb respondenta. Niezgodność tego wyniku z ustaleniami poczynionymi m.in. przez Bond i in. (2003) oraz Hill i in. (2008) może jednak wynikać ze specyfiki pytania zadawanego w badaniu GGS. Autorzy wcześniejszych badań odnosili się do możliwości korzystania z elastycznego czasu pracy w najpełniejszym znaczeniu tego pojęcia, a zatem zarówno w kontekście godzin pracy, jak i wymiaru jej świadczenia. Tymczasem w badaniu GGS respondenci mogli jedynie wskazać na istnienie lub brak możliwości kształtowania godziny rozpoczęcia pracy. Pojęcie elastyczności zatrudnienia rozumiane było zatem dość wąsko. Bez znaczenia dla poziomu konfliktu pozostawało również miejsce świadczenia pracy, rodzaj posiadanej umowy oraz parytet płci.

W modelu ujawniło się natomiast, zarówno dla kobiet, jak i mężczyzn, istotne znaczenie zadowolenia z pewności i stabilności zatrudnienia dla poziomu konfliktu pomiędzy rodziną a pracą. Wraz ze wzrostem poziomu zadowolenia z pracy, konflikt pomiędzy życiem rodzinnym a zawodowym malał. Dla mężczyzn istotne znaczenie dla poziomu konfliktu miał również sektor zatrudnienia. Ojców pracujących w sektorze publicznym cechował niższy poziom konfliktu niż tych, którzy świadczyli pozostawali w zatrudnieniu w sektorze prywatnym.

W zakresie dodatkowych świadczeń oferowanych przez pracodawców istotna, i tylko dla mężczyzn, okazała się możliwość podniesienia kwalifikacji. Ojcowie mający możliwość kształcić się dodatkowo na koszt pracodawcy wskazywali na wyższy poziom konfliktu niż ci, którzy nie mieli takiej możliwości. Efekt ten nie był widoczny natomiast dla kobiet. Może to się wiązać z tym, że kobiety generalnie bardziej są skłonne do podejmowania wysiłku dalszej edukacji czy doskonalenia umiejętności, nie traktując tego elementu jako czynnika nasilającego konflikt pomiędzy obowiązkami rodzinnymi i zawodowymi (Kotowska i in. 2007).

W odniesieniu do sytuacji rodzinnej respondenta, liczba dzieci w gospodarstwie domowym determinowała istotnie poziom konfliktu rodzina-praca u kobiet, podczas gdy u ojców istotny okazał się wiek najmłodszego dziecka. Matki posiadające troje lub więcej dzieci częściej wskazywały na niemożność (lub trudność) wywiązania się z obowiązków zawodowych, niż kobiety z jednym dzieckiem. Wynik taki jest 
zgodny z wcześniejszymi ustaleniami Notten i in. (2017). Z kolei ojcowie posiadający dzieci w wieku przedszkolnym (3-5 lat) cechowali się wyższym poziomem konfliktu pomiędzy rodziną a pracą niż ojcowie dzieci starszych. Dla stopnia zakłócenia wykonywania obowiązków zawodowych przez obowiązki rodzinne bez znaczenia okazał się być, zarówno dla kobiet, jak i dla mężczyzn, fakt zamieszkiwania z partnerem oraz konieczność sprawowania opieki nad osobą inną niż dziecko.

W grupie zmiennych kontrolnych nieistotny dla natężenia konfliktu pomiędzy rodziną a pracą zawodową okazał się - dla obu płci - wiek respondenta, jego miejsce zamieszkania oraz wykształcenie. W zakresie wykształcenia wynik ten pozostaje niezgodny z ustaleniami Notten i in. (2017), zgodnie z którymi respondentów o wyższych poziomach wykształcenia cechuje silniejszy konflikt pomiędzy rodziną a pracą. W przypadku kobiet w modelu ujawnił się istotny związek zdrowia z poziomem konfliktu pomiędzy obowiązkami rodzinnymi a zawodowymi. Matki deklarujące dobry lub bardzo dobry stan zdrowia cechował istotnie niższy poziom konfliktu niż kobiety określające swój stan zdrowia jako gorszy.

Podsumowując wyniki modelowania konfliktu pomiędzy rodziną a pracą zawodową warto wskazać, że oczekiwano, iż determinanty tego konfliktu, rozumianego jako stopień, w jakim obowiązki rodzinne utrudniają wykonywania pracy zawodowej, ujawnią się w szczególności w grupie zmiennych charakteryzujących sytuację rodzinną respondenta. Jednak wbrew oczekiwaniom związek sytuacji rodzinnej respondenta $\mathrm{z}$ nasileniem konfliktu rodzina-praca okazał się być niewielki. Bez znaczenia dla poziomu konfliktu był nie tylko fakt zamieszkiwania z partnerem, a zatem posiadanie w gospodarstwie domowym osoby, z którą można dzielić obowiązki rodzinne, ale również bez znaczenia okazała się być liczba (dla mężczyzn) i wiek (dla kobiet) posiadanych dzieci. Niespodziewanie jednak stopień, w jakim życie rodzinne zakłóca wykonywanie pracy zawodowej, okazał się pozostawać $\mathrm{w}$ istotnym związku z zadowoleniem ze stabilności i pewności zatrudnienia oraz w przypadku mężczyzn - z sektorem, w jakim pracowali.

\section{KONFLIKT PRACA-RODZINA}

W zakresie cech miejsca pracy, które mogą kształtować możliwości łączenia obowiązków rodzinnych i zawodowych, istotne znaczenie dla konfliktu praca-rodzina okazało się mieć zadowolenie z pewności i stabilności zatrudnienia Wynik ten dotyczy zarówno ojców, jak i matek i jest zgodny z wynikami uzyskanymi m.in. przez Cooklin i in. (2015) i Lawrence i in. (2013). Czas poświęcany na pracę zawodową okazał się istotnie determinować poziom konfliktu praca-rodzina jedynie u kobiet: wraz ze wzrostem czasu poświęcanego przez matki na pracę rósł poziom zakłócenia życia rodzinnego przez pracę zawodową. Podobne wyniki świadczące o nasileniu konfliktu praca-rodzina wraz ze wzrostem czasu poświęcanego na pracę w swoich badaniach uzyskali m.in. Notten i in. (2017) oraz Ruppanner i Pixley (2012). Konieczność nadzoru innych pracowników istotnie determinowała poziom konfliktu 
praca-rodzina u mężczyzn. Ojcowie nadzorujący innych pracowników wskazywali na wyższy poziom konfliktu, niż mężczyźni nie pełniący takiej roli, co wydaje się być spójne z ustaleniami Maume i Houston (2001) oraz Ruppanner i Pixley (2012).

Zaskakujące wyniki uzyskałyśmy w odniesieniu do możliwości ustalania godzin pracy w zależności od potrzeb pracownika. Wbrew naszym oczekiwaniom oraz wynikom uzyskanym m.in. przez Byron (2005) oraz Hill i in. (2008), rodzice mogący swobodnie ustalać godziny świadczenia pracy nie wskazywali na niższy poziom konfliktu niż ci, którzy nie mieli takiej możliwości. Rezultat ten, jak wspomniałyśmy, może wynikać ze sposobu sformułowania pytania w badaniu GGS. Poziom nasilenia konfliktu pomiędzy rolą rodzica a pracownika nie pozostawał również w związku, zarówno w przypadku mężczyzn, jak i kobiet, z sektorem zatrudnienia, rodzajem posiadanej umowy, miejscem świadczenia pracy ani parytetem płci.

Wśród wyróżnionych w modelu dodatkowych świadczeń oferowanych pracownikom, jedynym świadczeniem istotnie nasilającym poziom konfliktu praca-rodzina wśród ojców okazała się możliwość dodatkowego kształcenia. W grupie matek świadczeniem istotnie nasilającym konflikt okazała się możliwość korzystania z dodatkowego ubezpieczenia zdrowotnego lub opieki zdrowotnej.

Spośród zmiennych opisujących sytuację rodzinną respondenta, fakt posiadania partnera nie miał znaczenia dla nasilenia konfliktu praca-rodzina. Wyniki badań zagranicznych (Byron 2005, Winslow 2005), które wskazywały, że samotni rodzice doświadczają silniejszego konfliktu praca-rodzina niż osoby pozostające w związku, nie znalazły odzwierciedlenia w polskim kontekście. W naszym badaniu nie ujawnił się związek poziomu konfliktu z liczbą dzieci w rodzinie. Jest to odmienne od wyników badań zagranicznych (Notten i in. 2017), według których liczba dzieci w gospodarstwie domowym może determinować poziom konfliktu pomiędzy pracą zawodową a rodziną. W naszym modelu wiek najmłodszego dziecka, zarówno dla ojców, jak i matek, również nie determinował nasilenia konfliktu pomiędzy pracą zawodową a rodziną. Pozostaje to zbieżne z wynikami uzyskanymi przez Keene i Quadagno (2004).

W zakresie pozostałych charakterystyk społeczno-demograficznych, determinantami poziomu konfliktu praca-rodzina w grupie ojców dzieci do lat 14 okazały się wiek respondenta i poziom jego wykształcenia. Dla starszych respondentów poziom konfliktu pomiędzy pracą a rodziną osłabiał się, co może wynikać z faktu, że starsi respondenci mają zazwyczaj starsze dzieci. W zakresie wykształcenia natomiast, mężczyźni z wyższym poziomem wykształcenia wskazywali na niższy poziom konfliktu, niż ojcowie o najniższym wykształceniu. W modelu ujawniła się również istotna rola zdrowia dla poziomu konfliktu praca-rodzina. Rodzice dobrze oceniający swój stan zdrowia wskazywali na niższy poziom konfliktu pomiędzy pracą a obowiązkami rodzinnymi, co pozostaje zbieżne z ustaleniami Allen i in. (2000).

Konkludując, wyniki modelowania w zakresie konfliktu pomiędzy pracą a rodziną okazały się bardziej odpowiadać naszym oczekiwaniom. Determinantami nasilenia stopnia, w jakim praca zawodowa utrudnia wywiązywanie się z obowiąz- 
ków rodzinnych, okazały się być przede wszystkim charakterystyki miejsca pracy respondenta, $\mathrm{w}$ tym zadowolenie z pewności i stabilności zatrudnienia, czas poświęcany na pracę (dla kobiet) oraz wykonywanie, często odpowiedzialnych i obciążających zadań związanych z nadzorem innych pracowników (dla mężczyzn). Wiek oraz wykształcenie respondenta okazały się również istotnymi zmiennymi w przypadku mężczyzn. Bez znaczenia dla poziomu konfliktu okazała się natomiast sytuacja rodzinna respondenta. Wyjątkiem było ujawnienie się większego natężenia konfliktu praca-rodzina u kobiet posiadających co najmniej troje dzieci.

\section{UWAGI KOŃCOWE}

W przedstawionym badaniu dokonałyśmy dla Polski analizy determinant dwóch rodzajów konfliktu związanego z wykonywaniem pracy i obowiązków domowych, tj. negatywnego wpływu obowiązków rodzinnych na wykonywaną pracę oraz negatywnego wpływu wykonywanej pracy na obowiązki rodzinne. Analizę zrealizowałyśmy dla rodziców z dziećmi do lat 14, uznając tę grupę za najbardziej narażoną na występowanie obu rodzajów konfliktu. Odrębnie analizowaliśmy kobiety i mężczyzn ze względu na podział ról w rodzinie, a także na inną sytuację kobiet i mężczyzn na rynku pracy. W badaniu skupiłyśmy się na analizie związku wyróżnionych czynników dotyczących cech miejsca pracy, sytuacji rodzinnej respondenta oraz innych cech społeczno-demograficznych z poziomem każdego z tych konfliktów.

Uzyskane wyniki wskazują, że oba rodzaje konfliktu występują w polskim kontekście, choć większe natężenie ma konflikt na linii praca-rodzina. Chociaż poziom natężenia konfliktu praca-rodzina i rodzina-praca był zbliżony u kobiet i mężczyzn, to potwierdzone zostały nasze oczekiwania, że determinanty tego konfliktu są różne w zależności od płci.

Przeprowadzone analizy potwierdziły częściowo nasze oczekiwanie dotyczące związku warunków i organizacji pracy $\mathrm{z}$ dwoma rodzajami konfliktu. Ważną determinantą konfliktu pomiędzy pracą zawodową a rodziną oraz rodziną a pracą okazała się stabilność i pewność zatrudnienia. Niezależnie zatem od tego, czy analizie poddawano stopień, w jakim praca zawodowa uniemożliwia wywiązywanie się z obowiązków domowych, czy odwrotnie, poczucie konfliktu pomiędzy tymi konkurencyjnymi rolami było łagodzone poprzez postrzeganie pracy jako pewnej i stabilnej. Czas poświęcany na pracę zawodową okazał się istotnie determinować poziom konfliktu praca-rodzina, jednak jedynie u kobiet. Wbrew naszym oczekiwaniom rodzice mogący swobodnie ustalać godziny świadczenia pracy nie wskazywali niższego poziomu konfliktu praca-rodzina niż ci, którzy nie mieli takiej możliwości. Konieczność nadzoru innych pracowników istotnie determinowała poziom konfliktu praca-rodzina u mężczyzn. Nie stwierdzono natomiast istotnego związku pomiędzy poziomem konfliktu rodzina-praca a długością czasu pracy, możliwością kształtowania godzin pracy czy pełnieniem nadzoru na pracą innych. 
Częściowo potwierdzone zostały także nasze przypuszczenia dotyczące wpływu sytuacji rodzinnej respondenta związanej ze składem gospodarstwa domowego. Wyniki modelowania wykazały, że w przypadku mężczyzn natężenie konfliktu praca-rodzina było zależne od liczby posiadanych dzieci, a w przypadku konfliktu rodzina-praca - od ich wieku. W przypadku kobiet fakt posiadania trojga lub więcej dzieci był istotnie związany $\mathrm{z}$ tym, że obowiązki rodzinne utrudniały wywiązywanie się z pracy zawodowej. W modelu nie ujawniła się natomiast oczekiwana przez nas rola obecności małego dziecka (0-2 lata), a zatem dziecka, nad którym opieka wymaga największego zaangażowania czasu. Rezultat ten może jednak wynikać z faktu, że część respondentek, matek dzieci do lat 2, w momencie badania przebywała na urlopach rodzicielskich, co okresowo eliminowało konflikt na linii rodzinapraca dla nich i ich partnerów.

Interpretując powyższe wyniki należy mieć na uwadze, że w większości badań, w tym w GGS, warunki pracy badane są jedynie w stosunku do osób pracujących ${ }^{3}$. Są to osoby, które są w stanie zaakceptować pewien poziom natężenia konfliktu pomiędzy obiema aktywnościami życiowymi. Oznacza to, że respondenci tych badań poddani są do pewnego stopnia autoselekcji. Dodatkowo, skala tego zjawiska jest bardzo uzależniona od płci. Udział niepracujących matek w wieku 25-54 lata wśród ogółu matek w tej grupie wieku wynosi $30 \%$, dla mężczyzn zaś odsetek niepracujących ojców w tej grupie wieku kształtuje się na poziomie 6\%. Oznacza to, że kobiety częściej niż mężczyźni rezygnują z pracy po urodzeniu dziecka lub w ogóle nie podejmują aktywności zawodowej. Jedna z możliwych interpretacji tego zjawiska może wiązać się z podziałem ról społecznych w rodzinie, w którym większą część obowiązków opiekuńczych - szczególnie w okresie bezpośrednio po urodzeniu dziecka - przejmuje kobieta. W okresie tym mężczyźni często stają się głównym, lub wręcz jedynym, żywicielem rodziny. Dodatkowo dla części z nich niepracująca partnerka, sprawująca opiekę nad dzieckiem, zmniejszać może poziom konfliktu na linii rodzina-praca.

W praktyce oznacza to potrzebę prowadzenia szczegółowych badań osób znajdujących się poza rynkiem pracy pod kątem ich aktywizacji zawodowej, a także realizacji spójnej i przemyślanej polityki publicznej, w tym polityki rodzinnej i polityki rynku pracy, która mogłaby wspierać łączenie obowiązków rodzinnych i zawodowych. W tym kontekście uzyskane przez nas wyniki wskazują na obszary o istotnym znaczeniu dla pracujących rodziców dla subiektywnego poczucia konfliktu ma linii rodzina-praca.

\footnotetext{
${ }^{3}$ Kategoria ta obejmuje także osoby przebywające na czasowych urlopach związanych z urodzeniem lub wychowaniem dziecka.

${ }^{4}$ Dolne ograniczenie wieku wynika z potrzeby wykluczenia osób niepracujących z powodu nauki na studiach wyższych. Górne ograniczenie zaś wynika z faktu, że po 54 roku życia w próbie nie ma już wystarczającej liczby matek dzieci do 14 lat.
} 


\section{ŹRÓDŁO FINANSOWANIA}

Badanie zostało przygotowane w ramach projektu „Generacje, rodziny i płeć kulturowa (GGS-PL)” finansowanego przez Narodowe Centrum Nauki na podstawie umowy 2013/08/M/HS4/00421.

\section{LITERATURA}

Adams G.A., King L.A., King D.W., 1996, Relationships of job and family involvement, family social support, and work-family conflict with job and life satisfaction, „Journal of Applied Psychology”, 81(4), 411-420.

Allen T.D., Herst D.E.L., Bruck C.S., Sutton M., 2000, Consequences associated with work-to-family conflict: A review and agenda for future research, „Journal of Occupational Health Psychology”, 5(2), 278-308.

Baxter J., 2002, Patterns of change and stability in the gender division of household labour in Australia, 1986-1997, „Journal of Sociology”, 38, 399-424.

Bianchi S.M., Milkie M.A., 2010, Work and family research in the first decade of the 21st century, „Journal of Marriage and Family”, 72(3), 705-725.

Bond J.T., Thompson C., Galinsky E., Prottas D., 2003, Highlights of the 2002 National Study of the Changing Workforce, New York: Families and Work Institute.

Bowen G., 1998, Effects of leader support in the work unit on the relationship between work spillover and family adaptation, „Journal of Family and Economic Issues”, 19, 25-52.

Byron K., 2005, A meta-analytic review of work-family conflict and its antecedents, ,Journal of Vocational Behavior", 67, 169-198.

Comer D.R., Stites-Doe S., 2006, Antecedents and consequences of faculty women's academic-parental role balancing, ,Journal of Family and Economics Issue”, 27, 495-512.

Cooklin A.R., Giallo R., Strazdins L., Martin A., Leach L.S., Nicholson J.M., 2015, What matters for working fathers? Job characteristics, work-family conflict and enrichment, and fathers' postpartum mental health in an Australian cohort, „Social Science and Medicine”, 146, 214-222.

Craig L., Bittman M., 2008, The incremental time costs of children: An analysis of children's impact on adult time use in Australia, „Feminist Economics”, 14(2), 59-88.

Dilworth J.E.L., 2004, Predictors of negative spillover from family-to-work, „Journal of Family Issues”, 25(2), 241-261.

Duxbury L., Higgins Ch., 2001, Work Life Balance In The New Millennium: Where are we? Where we need to go?, CPNR Discussion paper no W/12 October.

Gauthier A.H., Furstenberg F.F., 2002, The transition to adulthood: A time use perspective, "The ANNALS of the American Academy of Political and Social Science", 580(1), 153-171.

Greenhaus J.H., Beutell N.J., 1985, Sources of conflict between work and family roles, „Academy of Management Review", 10(1), 76-88.

Gutek B., Searle S., Klepa L., 1991, Rational versus gender role expectations for work-family conflict, „Journal of Applied Psychology”, 76(4), 560-568.

Hartmann H., 2004, Policy alternatives for solving work-family conflict, „The Annals of the American Academy of Political and Social Science", 596, 226-231.

Hill E., 2005, Work-family facilitation and conflict, working fathers and mothers, work-family stressors and support, ,Journal of Family Issues”, 26(6), 793-819.

Hill E.J., Grzywacz J.G., Allen S., Blanchard V.L., Matz-Costa C., Shulkinn S., 2008, Defining and conceptualising workplace flexibility, „Community, Work \& Family”, 11(2), 149-163.

Kaźmierczak M., Chybicka A., 2008, Konflikt praca-rodzina a zadowolenie z relacji partnerskiejAnaliza wybranych czynników demograficznych, [w:] C. Sadowska-Snarska (red.), Równowaga praca-życie-rodzina (s. 328-338), Wydawnictwo Wyższej Szkoły Ekonomicznej, Białystok. 
Keene J.R., Quadagno J., 2004, Predictors of perceived work-family balance: Gender difference or gender similarity?, „Sociological Perspectives”, 47, 1-24.

Khan R.L., Wolfe D.M., Quinn R.P., Snoek J.D., Rosenthal R.A., 1964, Organizational stress: Studies in role conflict and ambiguity, New York.

Kocot-Górecka K., Kurowska A., 2013, Znaczenie postaw wobec kulturowych ról płci, rodzinnego wzorca pracy matek oraz podziału obowiązów domowych i rodzicielskich dla zatrudnienia matek matych dzieci w Polsce, „Studia Demograficzne”, 2(164), 35-57.

Kotowska I.E., Sztanderska U., Wóycicka I. (red.), 2007, Aktywność zawodowa i edukacyjna a obowiązki rodzinne w Polsce $w$ świetle badań empirycznych, Wydawnictwo Naukowe Scholar.

Lawrence E.R., Halbesleben J.R.B., \& Paustian-Underdahl S.C., 2013, The influence of workplace injuries on work-family conflict: Job and financial insecurity as mechanisms, „Journal of Occupational Health Psychology", 18, 371-383.

Marks S.R., 2006, Understanding diversity of families in the 21st century and its impact on the workfamily area of study, [w:] M. Pitt-Catsouphes, E.E. Kossek, S. Sweet (red.), The work and family handbook: Multidisciplinary perspectives, methods, and approaches (s. 41-65), New Jersey, NJ: Erlbaum.

Maume D., Houston P., 2001, Job segregation and gender differences in work-family spillover among white-collar workers, „Journal of Family and Economic Issues”, 22, 171-189.

Minnotte K.L., Minnotte M.C., Pedersen D.E., Mannon S., Kiger G., 2010, His and her perspectives. Gender ideology, work-to-family conflict and marital satisfaction, „Sex Roles”, 63, 425-438.

Notten N., Grunow D., Verbakel E., 2017, Social policies and families in stress. Gender and educational differences in work-family conflict from a European perspective, „Social Indicators Research", 132(3), 1281-1305.

Pedersen D.E., Minnotte K.L., Kiger G., Mannon S.E., 2009, Workplace policy and environment, family role quality, and positive family-to-work spillover, „Journal of Family and Economic Issues”, 30, $80-89$.

Peters P., Den Dulk L., Van der Lippe T., 2009, The effects of time-spatial flexibility and new working conditions on employees' work-life balance: The Dutch case, „Community, Work \& Family”, 12(3), 279-298.

Ruppanner L., Pixley J., 2012, Work-to-Family and Family-to-Work Spillover: The Implications of Childcare Policy and Maximum Work-Hour Legislation, „Journal of Family and Economic Issues", 33, 283-297.

Van der Lippe T., Van Dijk L. (red.), 2001, Women's employment in a comparative perspective. Sociology and economics, New York: Aldine de Gruyter.

Voydanoff P., 1988, Work-role characteristics, family structure demands, and work-family conflict, „Journal of Marriage and the Family”, 50, 749-761.

Voydanoff P., 2005a, The differential salience of family and community demands and resources for family-to-work conflict and facilitation, „Journal of Family and Economic Issues”, 26(3), 395-417.

Voydanoff P., 2005b, Toward a conceptualisation of perceived work-family fit and balance: A demands and resources approach, „Journal of Marriage and the Family”, 67, 822-836.

Winslow S., 2005, Work-family conflict, gender, and parenthood, 1977-1997, „Journal of Family Issues", 26, 727-755.

Zalewska A., 2011, Płeć i okres życia a konflikty praca-rodzina. Zadowolenie z pracy $i$ rodziny, [w:] L. Golińska, E. Bielawska-Batorowicz (red.), Rodzina i praca w warunkach kryzysu (s. 365-379), Wydawnictwo Uniwersytetu Łódzkiego. 


\title{
CONFLICT BETWEEN WORK AND FAMILY IN POLAND
}

\begin{abstract}
The aim of the paper is to present determinants of work-family conflict for working men and women in Poland. Two types of such conflict were studied - from work to family and from family to work. Due to the fact that mostly parents are exposed for those types of conflict, the analysis is restricted to men and women with children up to 14 years old. The analysis is conducted separately for men and women since differences in division of duties in families may result in differences in determinants of work-family conflict. We are interested in the influence of workplace and family characteristics on both types of conflict. The model analysis is based on data from the second wave of the Gender and Generations Survey for Poland. We conclude that in Poland both types of conflict exist, but the intensity of work-family conflict is bigger than family-work conflict. In case of each type of conflict, its intensity is similar for men and women, but the determinants of those types of conflict vary across gender.
\end{abstract}

Keywords: work-family conflict, spill over from family to work, spill over from work to family, reconciliation of work and family 
Konflikt pomiędzy praca zawodowa a obowiązami rodzinnymi w Polsce

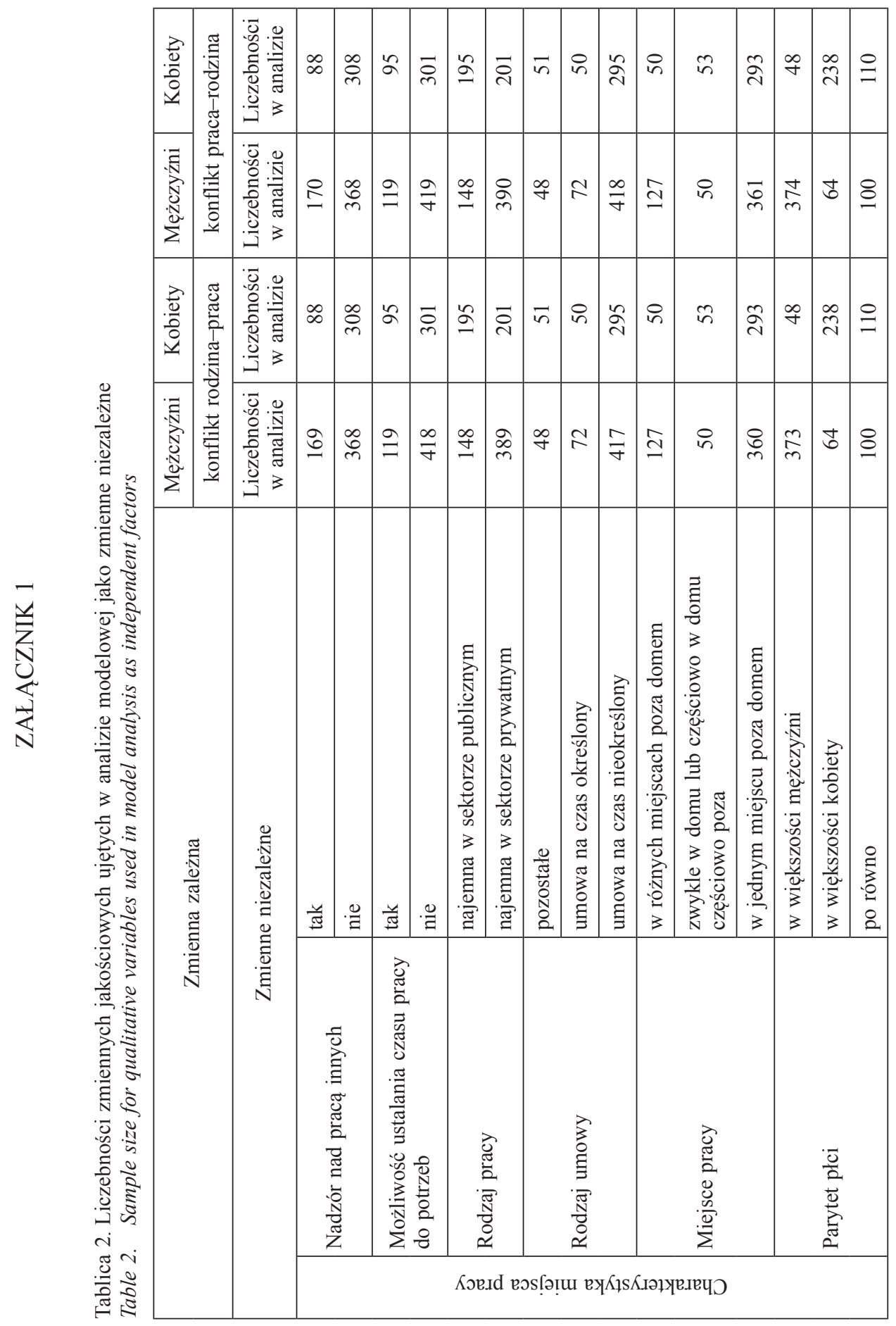




\section{Izabela Grabowska, Ewelina Stotwińska-Rosłanowska}

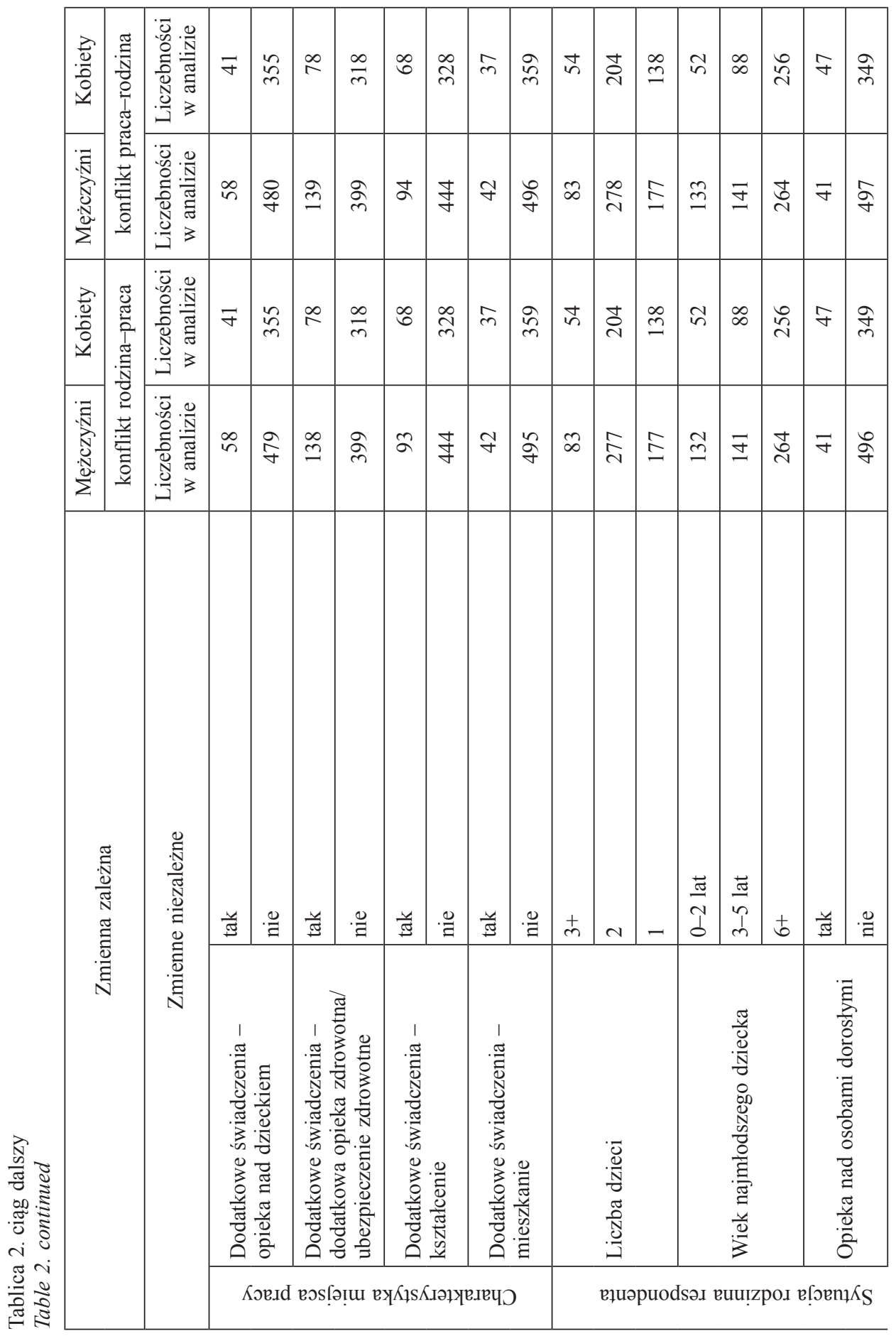




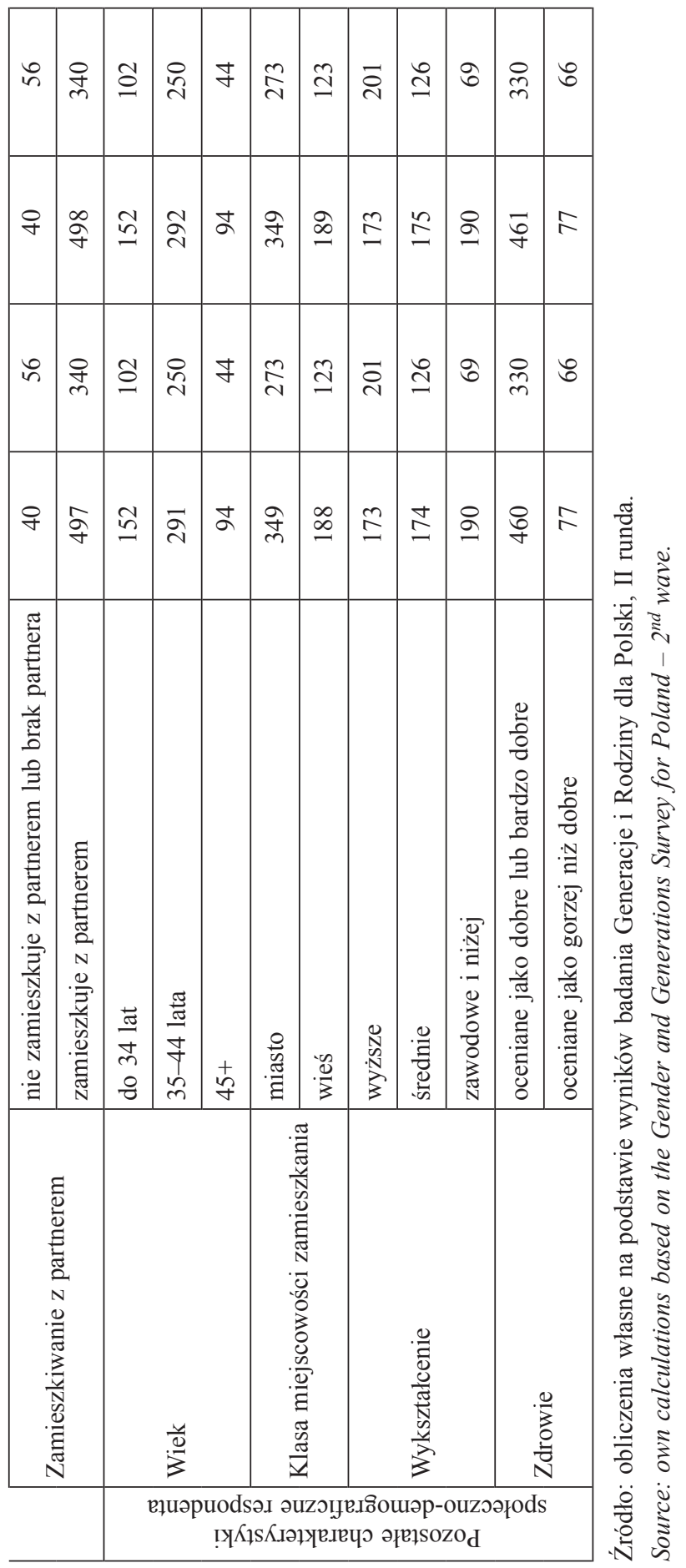

